\title{
Nursing and Antimicrobial Stewardship: An Unacknowledged and Underutilized Focal Point
}

\author{
Rosemarie R. Van Patten ${ }^{1 *} \&$ Anne S. Bartone ${ }^{2}$ \\ ${ }^{1}$ Siena College, Loudonville, NY, USA \\ ${ }^{2}$ Tompkins County Mental Health Services, Tompkins County, NY, USA \\ *Corresponding Author - Rosemarie R. Van Patten, Siena College, Loudonville, NY, USA Email: rvanpatten@ siena.edu \\ DOI: https://dx.doi.org/10.47988/janany.91819423.1.1
}

\begin{abstract}
Background: Nurses have the ability to play an important role in patient safety related to antibiotic use and overuse but are often not involved in antimicrobial stewardship programs (ASP). Therefore, nurses need to be educated and trained in antimicrobial stewardship (AS) so that they can more competently contribute to safe patient care. Lewin's change theory may be utilized as a framework for understanding the integration of nurses into these efforts.

Objective of the Study: This integrative review is intended to explore the role of nurses in AS and discuss the importance of nurses needing to be educated, trained, and competent in this so that they can become more actively involved in such programs.

Methodology: Articles were gathered from the Cumulative Index to Nursing and Allied Health Literature (CINAHL), PubMed, and Google Scholar from June 2015 to December 2019. A five-year time frame was implemented to ensure that the most current information was included. Seventeen peer reviewed, written in English, original research studies that met the inclusion criteria (from the original 107 studies) and conducted in Australia, Canada, Scotland, South Africa, and the United States were included in this review.

Results: The identified 17 recent studies focused on nursing and AS. Six major themes emerged, including nurses' competency requirements and training related to AS, antimicrobial knowledge and educational gaps, perceived role of the nurse, nurses' attitudes toward antimicrobial use, nurse and provider perspectives on ASPs, and nurses' valuable contributions to AS.

Discussion: This integrative review found that including nurses in AS would benefit ASPs and that finding ways for facilities to organize and implement such efforts is vital. This ties into the first stage of Lewin's change theory of "unfreezing" and recognizing that the current (or old) way of practicing is in need of change. The literature reviewed provides evidence that nurses have the capacity to be an integral part of any ASPs and that they can help combat antimicrobial resistance in myriad ways when provided the necessary training and education. All studies reviewed found positive aspects to having nurse representation. However, there are gaps in antimicrobial based knowledge on the part of the nurses.

Limitations: The limitations of this integrative review include the fact that the publications used were limited to a five-year timeframe and came specifically from nursing journals or have at least one nurse author contributor. Also, the current review included five international studies where the nurses' scope and standards of practice may be different from those in the United States. A search of the grey literature reports related to AS was not conducted and could have provided additional valuable information as well.

Conclusion and Recommendations: Nursing participation is needed in all ASPs. Empowering and educating nurses to feel confident and competent in this role will help to mitigate the overuse and misuse of antimicrobials. The ASPs most likely vary from institution to institution and future research should provide a framework for how to best disseminate information to nurses.
\end{abstract}

Keywords: Antimicrobial Stewardship, Antibiotic Training, Nurses

Funding: The authors did not receive any funding from the public, commercial, or not-for-profit sectors.

Conflict of Interest: The authors declare no actual or potential conflict of interest. 


\section{Nursing and Antimicrobial Stewardship: An Unacknowledged and Underutilized Focal Point}

The Centers for Disease Control and Prevention (CDC) and the World Health Organization (WHO) identified the development and spread of antimicrobial resistance as a global health crisis and a major public health concern (Abbas et al., 2019; Ha et al., 2019; Manning et al., 2016; R.N. Olans et al., 2016). Due to a convergence of factors-widespread overuse, improper adherence to treatment regimens, reluctance of pharmaceutical companies to research and develop new drugs, rapid and accessible international travel, and diffusion of antimicrobial organisms-optimal conditions now exist for a "perfect storm" (R.N. Olans et al., 2016, p. 84), wherein infectious agents become resistant to all available pharmaceutical remedies. Awareness of the potential development of antimicrobial resistance was present as early as 1939 and 1945, but the lure of the "miracle drugs" overshadowed this concern (R.N. Olans et al., 2016, p. 84). It was not until 1988 that the concept and serious planning around Antimicrobial Stewardship Programs (ASPs) began (R.D. Olans et al., 2015) and it has been only since 2017 that The Joint Commission (TJC) required them. The Society for Healthcare Epidemiology of America (SHEA), the Infectious Diseases Society of America (IDSA), and the Pediatric Infectious Diseases Society (PIDS, 2012) define antimicrobial stewardship (AS) as the "coordinated interventions designed to improve and measure the appropriate use of antimicrobial agents by promoting the selection of the optimal antimicrobial drug regimen including dosing, duration of therapy, and route of administration" (p. 323). Hamdy et al., (2019) add that nurses are "in a unique position to fully ensure that all patient care needs are met when an antibiotic is prescribed" (p. 10) due to the fact that they are involved in most aspects of patient care and often interact with the patient more than any other health care professional. Formal stewardship teams were defined in 2001 and the key disciplines initially identified as essential to facilitate these programs in health care settings were pharmacists, microbiologists, infectious disease specialists, infection control, and attending physicians (R.D. Olans et al., 2015; R.N. Olans et al., 2016).

The one most obvious and most often overlooked professional link absent in this chain is the nurse. This is despite the fact that the nurse holds a vital role in patient care and has many clinical responsibilities related to patient safety (Cadavid et al., 2017; Hamdy et al., 2019; Jeffs et al., 2018; R.N. Olans et al., 2016). The significance of this glaring omission becomes clear when recognizing that it is the registered nurse who interfaces with the patient, the pharmacist and the ordering provider, and is responsible for the initial triage, assessing sensitivity versus allergy, and reporting progress, in both residential and in-patient settings. Moreover, it is the nurse who administers and assesses medications, acts as the patient advocate, and is, most often, the healthcare professional that patients and families see and trust the most (Cadavid et al., 2017; Carter et al., 2018; R.N. Olans et al., 2016). Educating nurses to serve as conduits between other medical personnel and the patient clearly becomes essential for any ASP to function optimally (Greendyke et al., 2018). In 2019, the CDC recognized the contribution of nurses in AS efforts by including them in their initiative to implement hospital-based antimicrobial programs (CDC, 2020). Furthermore, while the Centers for Medicare \& Medicaid Services (CMS) developed regulations at the Federal level for ASPs in hospitals, nurses were not key contributors. A limited amount of research is currently available that specifically addresses the utilization of nurses as essential stakeholders in the fight against antimicrobial resistance. With the research that is currently available, the purpose of this integrative review is to explore the role of the nurse in AS and discuss the importance of nurses needing to be educated, trained, and competent in AS in order for them to become more actively involved in ASPs. Based on Lewin's theory, successful change, such as incorporating nurses into AS efforts, occurs when using a planned approach. Lewin's 3-step model of change (1951) includes: unfreezing [the current or old way of practicing is in need of change], moving to a new level [change is introduced], and refreezing [incorporating the new way] (Kelly, 2008). During "unfreezing," nurses encounter difficulties as they rethink old ways of practicing for the purposes of quality improvement. "Moving to a new level" ideas are presented to decrease inappropriate antimicrobial use, cut costs, and most importantly, improve patient outcomes. Finally, once the nurse acquires the training and knowledge base needed for active participation in ASPs, comfort and confidence help them transition in their new role ("refreezing").

\section{Method}

A search of the Cumulative Index to Nursing and Allied Health Literature (CINAHL), PubMed, and Google Scholar originally yielded 107 articles and of these, twenty-two articles were full text, peer reviewed, written in English, and original research studies published between June 2015 and December 2019. The five-year time frame was implemented to ensure that the most current information was included. Data were collected within the selected studies from September 2012 to March 2018. The studies were conducted in Australia, Canada, Scotland, South Africa, and the United States. Only articles that discussed nurse participation were included since that was the main focus of this review. Five were excluded from the final analysis because the articles were either not published in a nursing journal, did not include a registered nurse as a co-author, or did not discuss nurse participation. The search terms included (nurses OR nursing) AND (antimicrobial OR antibiotic) AND (stewardship OR education OR training). A total of nine (9) quantitative, five (5) qualitative, and three (3) mixed method studies met the inclusion criteria. Nurses working in different specialty areas (e.g., nurses working in nursing homes, infection control), with varying levels of education and roles (e.g., licensed practical nurses (LPN), registered nurses (RN), advanced practice nurses (APN) participated, but the focus of this integrative review was on the non-prescribing nurse. The authors of this paper independently read and reviewed each article several times. Each author then separately identified key themes that emerged from each article. The authors subsequently met to share their initial theme related findings and discussed associated rationales. This process allowed the authors to revise and refine 
findings and ultimately reach consensus about important and reoccurring themes. At the conclusion of this process, six themes were identified.

\section{Results}

This paper identified 17 recent studies focused on nursing, AS, and ASPs. The major themes found were nurse's competency requirements and training related to $A S$, knowledge and training/ educational gaps related to AS, perceived role of the nurse in $A S$, nurses' attitudes toward antimicrobial use, nurse and provider perspectives on ASP, and nurses valuable contributions to AS. Table 1 lists the articles and themes identified. Many articles had more than one major theme as evidenced below.

\section{Competency Requirements and Training Related to Antimicrobial Stewardship}

Cadavid et al. (2017) found 29 of the 34 hospitals studied required bedside nurses to be competent in at least one of ten antimicrobial education topics. However, the education topics or competency requirements varied significantly among the surveyed hospitals. Although $91 \%(n=31)$ of the hospitals reported that registered nurses received microbiology laboratory results, only $47 \%(\mathrm{n}=16)$ required competency or education related to interpreting culture and sensitivity results. Five hospitals responded that no registered nurses participated in their ASPs despite nurses' significant role in antimicrobial administration and monitoring (e.g., responsibility for assessing medication allergies before the provider puts in an antimicrobial order). The hope was that by ensuring nurse competency in several related areas (e.g., medication timing, treatment specificity of antimicrobials, and identification of broad-spectrum antimicrobials), there would be an increase in compliance to and adherence with antimicrobial stewardship activities across disciplines.

\section{Knowledge and Training/Educational Gaps Related to Antimicrobial Stewardship}

Eight articles addressed the need to strengthen nursing knowledge and encourage training related to AS so that nurses are able to contribute most effectively in ASPs. For example, Abbas et al. (2019) assessed nursing staff and found gaps in their knowledge related to AS. Specifically, results suggested that even with a majority of the participants being familiar with the term "antimicrobial stewardship," over $80 \%$ reported they have never had any AS training. Aligned with that, over $80 \%$ never communicated (or knew how to get in contact) with their hospital's ASP. Similarly, Kistler et al. (2017) examined the knowledge, attitudes, and behaviors regarding suspected infections among nurses working with older adults. A majority of participants were aware of the issues associated with "misuse and overuse" and showed attitudes and behaviors that aligned with the most recent evidence in this realm. However, results also showed that nurses needed to advance their knowledge base, as well as their attitudes and behaviors related to antibiotic overuse and misuse. Additionally, given the fact that TJC has designated nurses as "primary protectors" of patient safety, (R.N. Olans et al., 2016) focused on exploring how nurses could most effectively contribute to ASPs. Results of the study showed the need for nurses to develop a knowledge base in several areas (Table 1) before they can provide important contributions in this domain.

This review included further examination of barriers to knowledge and training. For instance, Monsees et al., (2018) evaluated the AS based knowledge and practices of pediatric nurses. The results suggested barriers existed, such as nurses not being part of medical rounds, power differentials among members of the interdisciplinary team, and nurses not being asked for their input. There is evidence that improving the knowledge base, specifically in terms of topics related to microbiology and antibiotics, along with consistently including nursing staff in the aforementioned activities, is essential. Fisher et al. (2018) also found that nurses have the ability to enhance AS activities by promoting IV to PO step-down of antimicrobials. However, nurse participants mentioned insufficient knowledge as one of the main modifiable barriers.

Training and education is key to maximizing nursing-based contributions. For example, Wilson et al. (2017) assessed nurses' knowledge and found that AS related knowledge improved after nurses participated in an educational online course offering. Nurses felt more confident contributing to the ASP in the long-term care facilities they were working in after completing the course. Empowering nurses to feel informed and important to the team can help reduce unnecessary antibiotic use in nursing homes as well. Likewise, Carter et al. (2018) underscored the fact that while nurses are in an ideal position to optimize appropriate antibiotic use, nurse participants consistently admitted knowledge gaps related to antibiotics in general. In addition to formal education and training, nurses in this sample suggested a need to have access to educational tools for reference. Finally, Greendyke et al. (2018) found that nurses generally feel that they can contribute to AS related activities. However, results also showed a need to educate nurses on the general principles of AS, so that they are able to make important contributions in this domain.

\section{Role of the Nurse in Antimicrobial Stewardship}

Six articles addressed the important role of the nurse as it relates to AS. For instance, Greendyke et al. (2018) found that nurses were generally eager to learn more about being an active member of an ASP. About one third of the participants $(n=145)$ felt that they could play an important role in AS by ensuring needed interventions (e.g., proper allergy histories, prioritization of antimicrobial administration, proper technique for obtaining blood cultures, and antimicrobial de-escalation) to lower inappropriate utilization of antimicrobials. On the other hand, Merrill et al. (2019) surveyed 316 nurses from three hospitals in Utah and found that about $50 \%$ of the participants did not understand their role in AS, despite recognizing that they were essential in the fight against antimicrobial resistance. Thus, education should focus on increasing nurses' knowledge on AS and how they can be utilized in the most efficient ways. About $60 \%$ of nurses in this study acknowledged the importance of antimicrobial stewardship and were enthusiastic about participation in related activities.

In an earlier study, McGregor et al. (2015) assessed knowledge of AS among 901 nurses based on the recognition that this group 
of professionals is becoming more and more important in their role as administrators of antimicrobials. Specifically, the results suggested that the "role" of the nurse should include ensuring appropriate antimicrobial use (including the assurance of correct duration and prevention of overuse), a good working (and up to date) knowledge of antimicrobial guidelines, and education (e.g., educating colleagues and patients about use and challenging prescribing decisions). In a more focused setting, Rout and Brysiewicz (2017) highlighted the essential role of the intensive care unit (ICU) nurse within the AS team as vital to the success of AS in the ICU. The four categories found in the study were advocacy, organizational, clinical, and collaborative roles of the nurse. The nurse had various roles in ASPs: advocacy (reminding prescribers of antimicrobial duration for each patient), clinical (monitoring infections and progress of antimicrobial treatment), organizational, and collaborative (interaction with members of the AS team). Similarly, Hamdy et al. (2019) conducted a focus group study to assess pediatric nurses' perceptions of their role in antimicrobial stewardship. A total of five major themes were identified, including advocacy, communication, administering medications safely, and education (for both caregivers and the nurses themselves). Subthemes were also discussed within the context of each main theme (Table 1).

Additionally, Stuart et al. (2015) assessed the role of the infection control clinical nurse consultant (CNC) and found that using a CNC to drive the ASP was associated with less antibiotic use in two residential care facilities. The CNC acted as the mediator between and among infectious disease specialists, general practitioners, and nurses, in interpreting lab results and patient signs and symptoms. By so doing, significant changes in antibiotic use were found.

\section{Nurses' Attitudes Toward Antimicrobial Use}

In addition to discovering knowledge gaps related to $\mathrm{AS}$, Carter et al. (2018) and Kistler et al. (2017) explored the attitudes of nurses regarding the use of antibiotic therapy. Carter et al. (2018) focused on nurse-driven antibiotic stewardship practices (Table 1) and found some of these to be perceived as an extension of the nurse's role as patient advocate. The authors also found that nurses had positive attitudes toward participating in AS and becoming more knowledgeable about their role. Kistler et al. (2018) focused on nurses working in nursing homes and found that nurse attitudes and behaviors demonstrated evidence-based knowledge, but suggested that improvement in the knowledge, attitudes, and behaviors could help decrease the overuse of antibiotic therapy.

\section{Nurse and Provider Perspectives on ASP}

Scales et al. (2016) found that both nurses and medical providers support AS and are committed to reducing unnecessary antibiotic use (but with medical providers more often than nurses). Both groups (medical providers and nurses) reported that patients and family members prefer antibiotic use and sometimes influence subsequent treatment decisions. Results also suggest that nurse leaders and medical providers working in long-term care may be particularly effective in AS efforts. Part of this is due to the fact that providers working in this subspecialty have reported an increased level of influence by patients and their families on prescribing decisions.

\section{Valuable Contributions to Antimicrobial Stewardship}

Ha et al. (2019) found that a multidisciplinary approach to AS is needed and that it is critical for nurses to be involved. As such, the bedside nurse is a valuable contributor to ASPs and any infection prevention strategies. Results suggest that there was a significant reduction in antimicrobial use when nurses were involved (791.2 vs. 697.1 days of therapy per 1,000 patient-days). Likewise, Jeffs et al. (2018) conducted focus group interviews of 11 pharmacists, 7 physicians and 6 nurses. Participants described the importance of engaging nurses in ASPs to enhance the culture of AS, to ensure easier and timely program implementation and to sustain the success of ASPs. They suggested that engaging nurses in ways that recognize their valuable contributions on ASPs is essential while more efforts are needed for nursing leadership to encourage and engage nurses in all phases of the program.

\section{Discussion}

This integrative review found that engaging nurses in AS would benefit ASPs and that finding ways for facilities to organize and implement such efforts is vital. This ties into the first stage of Lewin's change theory of "unfreezing" and recognizing that the current (or old) way of practicing is in need of change. The literature reviewed provides evidence that nurses have the capacity to be integral to any ASP and they can help combat antimicrobial resistance in myriad ways when provided the necessary training and education. All studies reviewed found positive aspects to having nurse representation in ASPs. However, based on the literature reviewed, it was also clear that there are gaps in antimicrobial based knowledge on the part of the nurse. The findings from several studies provide evidence that educated and knowledgeable nurses are willing to question prescribing providers about antibiotic management and whether or not there is a need for antibiotic use (both initial and continued use).

Staff nurses play a critical role in antimicrobial therapy in a variety of ways and stages: hospital admission, discharge, and outpatient care. The White Paper jointly issued by ANA and CDC (2017) outlined 15 areas that nurses can contribute to ASP but nurses' roles were unrecognized. They include (1) appropriate triage and isolation; (2) accurate antibiotic allergy history; (3) early and appropriate cultures; (4) timely antibiotic initiation; (5) progress reporting; (6) reviewing and communicating laboratory and radiology reports; (7) antibiotic dosing, culture and sensitivity reporting, and de-escalation; (8) monitoring and reporting adverse events; (9) reviewing patient clinical status and changes in medications; (10) tracking antibiotic resistance and patient response; (11) reporting bug/drug mismatch; (12) monitoring patient's capacity to transit from IV to PO antibiotic; (13) monitoring patient's progress 24/7; (14) educating patient and family; and (15) transition and re-admission management.

Nevertheless, the role of nursing in ASPs is only beginning to be investigated and still lacks standard protocol. R.D. Olans et al., (2015) explored how nurses could be included in the design of these programs and the elements needed to accomplish this goal. 
They suggested offering an educational program that focused on six areas (see Table 1) as a good starting point and is necessary before nurses can make meaningful contributions to any ASP. Furthermore, online courses may be one way to improve nursing knowledge related to AS activities and can encourage nurses to make positive changes in their work settings, thereby improving the overall quality of care that they provide. This is aligned with Lewin's second step, "moving to a new level," where change or intervention is introduced. The benefits and disadvantages are discussed, and change is implemented (Kelly, 2008). In this phase, nurses transition to a new level by learning about AS and ASPs in order for them to feel competent in collaborating and participating in related activities.

Including nurses in ASPs was found to improve quality of care and safe practice (Cadavid et al., 2017). For example, bedside nurses are responsible for assessing allergies to medication before administration. In addition, nurses often enter verbal medication orders for antimicrobials, offering an opportunity for them to discuss indications with the prescribing provider. Findings also suggest that bedside nurses are able to recognize broad-spectrum antibiotics, interpret cultures, monitor therapeutic levels, and assess treatment for suitability when they are appropriately educated regarding AS. These functions ultimately help reduce the spread of antimicrobial resistance. Nurses play an essential role in administering and evaluating antimicrobial treatment, as well as implementing evidence-based interventions. In the third and final step of Lewin's change theory, "refreezing" occurs, where the new way of doing is incorporated into the routines or habits of affected individuals (Kelly, 2008). With the utilization of nurses on ASPs, there is the potential for increased compliance with and adherence to related activities. The 17 studies reviewed offer support for the inclusion of nurses in AS as well as insights for organizing and implementing such efforts.

The limitations of this integrative review include the fact that it was limited to a five-year timeframe yielding only 17-peer reviewed qualitative, quantitative, and mixed method studies, specifically from nursing journals or those that had at least one nurse contributor. Those that did not meet these qualifiers were excluded. The five year time frame was implemented to ensure the most current information was included. Future researchers might consider reviewing non-nursing publications over a ten year timeframe to assess for potential differences. Moreover, the articles in this review included five international studies where the scope and standards of practice may differ from those in the U.S. Also, a search of the grey literature reports related to AS was not conducted and could have provided additional valuable information. The ASPs most likely vary from institution to institution and future research should provide a framework for how to best disseminate information and education to nurses. With that, an increased level of confidence and competence is likely. Finally, additional studies that are randomized controlled trials should be conducted in order to ensure the rigor, validity, and reliability.

\section{Conclusion}

Because both the CDC and the WHO have identified the emergence and spread of antimicrobial resistance as a global health crisis and a grave threat to human health, it is imperative that nursing professionals have AS components included as requirements in their curriculum. It is also essential that all health care institutions include first-level nursing professionals in their ASP teams due to the pivotal roles' nurses play as patient advocates and educators, principal patient assessors, medication monitors and administrators, and mediators between the patient and other medical personnel. Lewin's theory of change fits well when trying to conceptualize and integrate changes in any healthcare setting, and the inclusion of nurses into ASPs is no exception. The ASP paradigm will achieve its optimal potential with nurses recognized and embraced for their important role and contribution. 
Table 1

Summary of Reviewed Literature

\begin{tabular}{|c|c|c|c|c|c|}
\hline $\begin{array}{c}\text { Author/ Year/ } \\
\text { Country }\end{array}$ & Aim & $\begin{array}{l}\text { Research Type/ } \\
\text { Sample }\end{array}$ & $\begin{array}{l}\text { Theme(s) in } \\
\text { this review }^{\text {a }}\end{array}$ & Key Findings & Limitations \\
\hline $\begin{array}{l}\text { Abbas et al. } \\
\text { (2019) United } \\
\text { States }\end{array}$ & $\begin{array}{l}\text { To ascertain } \\
\text { the attitudes, } \\
\text { knowledge, } \\
\text { practice, and } \\
\text { barriers related to } \\
\text { the participation } \\
\text { of nurses in } \\
\text { antimicrobial } \\
\text { stewardship (AS) } \\
\text { and antimicrobial } \\
\text { stewardship } \\
\text { programs (ASP) }\end{array}$ & $\begin{array}{l}\text { Quantitative cross- } \\
\text { sectional study/ } \\
\mathrm{n}=159 \text { nursing staff } \\
\text { members from an } \\
850 \text {-bed tertiary } \\
\text { care academic } \\
\text { center in Richmond, } \\
\text { VA that had a well- } \\
\text { organized ASP for } 2 \\
\text { decades }\end{array}$ & Theme 2 & \begin{tabular}{|l|} 
- 120 nurses were \\
unaware of the ASP at \\
the facility \\
102 participants \\
indicated familiarity \\
with AS along with \\
concerns over physician \\
pushback and time \\
constraints related to \\
participants \\
- 31 nurses stated they had \\
formal training on AS \\
Gaps in knowledge \\
were discovered in \\
the area of AS and the \\
communication between \\
nurses and ASPs
\end{tabular} & $\begin{array}{l}\text { - Only one facility that } \\
\text { had a well-resourced } \\
\text { ASP in place for } \\
\text { two decades was } \\
\text { included in the study } \\
\text { - The survey was } \\
\text { distributed via a } \\
\text { list serve that went } \\
\text { out to } 3,485 \text { nurses } \\
\text { made it difficult to } \\
\text { determine the exact } \\
\text { number of active } \\
\text { nursing staff reached } \\
\text { Demographic } \\
\text { information for the } \\
\text { participants was not } \\
\text { obtained }\end{array}$ \\
\hline $\begin{array}{l}\text { Cadavid et al. } \\
\text { (2017) United } \\
\text { States }\end{array}$ & $\begin{array}{l}\text { To evaluate the } \\
\text { antimicrobial } \\
\text { related training and } \\
\text { education provided } \\
\text { to bedside RNs in } \\
\text { acute-care hospitals } \\
\text { in Los Angeles } \\
\text { County }\end{array}$ & $\begin{array}{l}\text { Quantitative, online } \\
\text { survey/n=34 nurse } \\
\text { educators from } 34 \\
\text { hospitals }\end{array}$ & Theme 1 & $\begin{array}{l}\text { In } 97 \% \text { ) of the hospitals, } \\
\text { nurses are responsible } \\
\text { for assessing medication } \\
\text { allergies prior to the } \\
\text { provider placing the } \\
\text { antimicrobial order } \\
\text { - In } 91.1 \% \text { of the } \\
\text { hospitals, nurses are } \\
\text { offered training on or are } \\
\text { required to understand } \\
\text { the correlation between } \\
\text { the use and resistance of } \\
\text { antimicrobials }\end{array}$ & $\begin{array}{l}\text { Rate of response was } \\
\text { low }(37 \% / \mathrm{n}=34)\end{array}$ \\
\hline
\end{tabular}




\begin{tabular}{|c|c|c|c|c|c|}
\hline $\begin{array}{l}\text { Carter et al. } \\
\text { (2018) United } \\
\text { States }\end{array}$ & $\begin{array}{l}\text { To explore the } \\
\text { attitudes of nurses } \\
\text { and infection } \\
\text { preventionists (IPs) } \\
\text { toward the nurse- } \\
\text { driven antibiotic } \\
\text { stewardship } \\
\text { activities of: 1) } \\
\text { questioning the } \\
\text { medical necessity } \\
\text { of urine cultures; } \\
\text { 2) ensuring } \\
\text { proper urine and } \\
\text { blood culturing } \\
\text { techniques; 3) } \\
\text { initiating the } \\
\text { switch from IV } \\
\text { to PO antibiotics; } \\
\text { 4) obtaining and } \\
\text { recording an } \\
\text { accurate penicillin } \\
\text { drug allergy history; } \\
\text { and 5) initiating an } \\
\text { antibiotic timeout) } \\
\text { recommended } \\
\text { by the American } \\
\text { Nurses Association } \\
\text { (ANA)/CDC } \\
\text { working group }\end{array}$ & $\begin{array}{l}\text { Qualitative, } \\
\text { focus groups and } \\
\text { semi-structured } \\
\text { interviews/n=49 } \\
\text { convenience } \\
\text { sampling, clinical } \\
\text { nurses, } 5 \text { nurse } \\
\text { managers, and } 7 \text { IPs } \\
\text { in } 2 \text { hospitals }\end{array}$ & $\begin{array}{l}\text { Themes } 2 \\
\text { and } 4\end{array}$ & $\begin{array}{l}\text { While participants were } \\
\text { excited about contributing } \\
\text { to antibiotic stewardship } \\
\text { efforts, they describe } \\
\text { several barriers that } \\
\text { challenge the activities } \\
\text { recommended by the } \\
\text { ANA/CDC including (1) } \\
\text { unaddressed knowledge } \\
\text { needs; (2) discomfort in } \\
\text { questioning prescribers } \\
\text { orders; (3) lack of ongoing } \\
\text { formal education in } \\
\text { culturing techniques; (4) } \\
\text { lack of accountability } \\
\text { regarding proper } \\
\text { techniques; (5) lack of } \\
\text { awareness of negative } \\
\text { consequences that result } \\
\text { from poor culturing } \\
\text { techniques; (6) family } \\
\text { push-back; (7) outside the } \\
\text { nurses' scope of practice; } \\
\text { (8) knowledge needs and } \\
\text { gaps; (9) prescriber push- } \\
\text { back; (10) patient-level } \\
\text { considerations; and (11) } \\
\text { lack of perceived value to } \\
\text { nurse-initiated antibiotic } \\
\text { time-outs as antibiotics are } \\
\text { already closely monitored } \\
\text { by prescribers and Pharm } \\
\text { D. Questioning the need for } \\
\text { urinary cultures, obtaining } \\
\text { cultures using proper } \\
\text { collection techniques, and } \\
\text { initiating the switch from } \\
\text { IV to PO antibiotics were } \\
\text { the three recommendations } \\
\text { viewed as most favorably } \\
\text { by this sample. Ensuring } \\
\text { an accurate penicillin } \\
\text { drug allergy history and } \\
\text { initiating an antibiotic } \\
\text { timeout were two other } \\
\text { recommendations met with } \\
\text { resistance because they } \\
\text { were perceived to exceed a } \\
\text { nurse's scope of practice. } \\
\end{array}$ & $\begin{array}{l}\text { Generalizability issues } \\
\text { due to the study being } \\
\text { conducted at two } \\
\text { academic teaching } \\
\text { hospitals in NYC. }\end{array}$ \\
\hline
\end{tabular}




\begin{tabular}{|c|c|c|c|c|c|}
\hline $\begin{array}{l}\text { Fisher et al. } \\
\text { (2018) Canada }\end{array}$ & $\begin{array}{l}\text { To assess the } \\
\text { barriers and } \\
\text { facilitators of } \\
\text { nurse's knowledge, } \\
\text { role, and behavior } \\
\text { regarding AS and } \\
\text { the promotion } \\
\text { of intravenous } \\
\text { (IV) to oral (PO) } \\
\text { antimicrobials by } \\
\text { nurses }\end{array}$ & $\begin{array}{l}\text { Qualitative, } \\
\text { prospective, } \\
\text { descriptive study/ } \\
\mathrm{n}=15 \text { bedside } \\
\text { nurses (RNs and } \\
\text { LPNs) working on a } \\
\text { medical or surgical } \\
\text { unit in } 3 \text { different } \\
\text { environments } \\
\text { (general medicine } \\
\text { and stroke care } \\
\text { unit; a general and } \\
\text { vascular surgery } \\
\text { unit; and an } \\
\text { oncology general } \\
\text { medicine unit) in } \\
\text { a 400-bed tertiary } \\
\text { referral hospital }\end{array}$ & Theme 2 & $\begin{array}{l}\text { - } 9 \text { themes identified as } \\
\text { barriers that included } \\
\text { insufficient knowledge, } \\
\text { lack of prescriber } \\
\text { cooperation, step down } \\
\text { viewed as role of the } \\
\text { prescriber, and lack of } \\
\text { self-confidence } \\
9 \text { themes identified as } \\
\text { facilitators that included } \\
\text { capability of actively } \\
\text { participating in team } \\
\text { rounds, confidence in } \\
\text { ability to promote IV } \\
\text { to PO step down with } \\
\text { support of colleagues } \\
\text { and other health care } \\
\text { professionals } \\
\text { Nurses also realized that } \\
\text { an increase in the step } \\
\text { down IV to PO rates } \\
\text { would increase nursing } \\
\text { efficiency } \\
\end{array}$ & $\begin{array}{l}\text { - One tertiary hospital } \\
\text { used } \\
\text { - } \text { Small sample size } \\
(\mathrm{n}=15) \\
\text { - } \text { Interviews were } \\
\text { used instead of focus } \\
\text { groups where more } \\
\text { possible barriers and } \\
\text { facilitators may have } \\
\text { been revealed }\end{array}$ \\
\hline $\begin{array}{l}\text { Greendyke } \\
\text { et al. (2018) } \\
\text { United States }\end{array}$ & $\begin{array}{l}\text { To explore the } \\
\text { knowledge, } \\
\text { attitudes, practice, } \\
\text { and role of the } \\
\text { bedside nurse } \\
\text { in antimicrobial } \\
\text { stewardship }\end{array}$ & $\begin{array}{l}\text { Quantitative, } \\
\text { descriptive study/ } \\
\text { Five acute- } \\
\text { care hospitals } \\
\text { participated } n=451 \\
\text { nurses }\end{array}$ & $\begin{array}{l}\text { Themes } 2 \\
\text { and } 3\end{array}$ & $\begin{array}{l}\text { The need to educate } \\
\text { nurses on antimicrobial } \\
\text { stewardship was found } \\
\text { especially in areas of } \\
\text { allergy histories, blood } \\
\text { culture techniques, } \\
\text { antimicrobial de- } \\
\text { escalation, and } \\
\text { prioritizing antimicrobial } \\
\text { administration. With the } \\
\text { large number of practicing } \\
\text { nurses this could make } \\
\text { for a significant decline in } \\
\text { inappropriate antimicrobial } \\
\text { use. }\end{array}$ & $\begin{array}{l}\text { Relatively low response } \\
\text { rate, the respondents } \\
\text { may not be generalized } \\
\text { among all nurses }\end{array}$ \\
\hline $\begin{array}{l}\text { Ha et al. } \\
(2019) \text { United } \\
\text { States }\end{array}$ & $\begin{array}{l}\text { To investigate } \\
\text { the need for } \\
\text { multidisciplinary } \\
\text { approaches to ASP } \\
\text { to include bedside } \\
\text { nurse involvement }\end{array}$ & $\begin{array}{l}\text { Quantitative, } \\
\text { retrospective } \\
\text { evaluation } / \mathrm{n}=\text { an } \\
\text { evaluation of AS } \\
\text { rounds conducted } \\
\text { on a 31-bed medical } \\
\text { telemetry step-down } \\
\text { unit in a 417-bed } \\
\text { community regional } \\
\text { medical center }\end{array}$ & Theme 6 & $\begin{array}{l}\text { Significant reductions in } \\
\text { unit antimicrobial use was } \\
\text { found when compared } \\
\text { with the } 12 \text {-month } \\
\text { preintervention period } \\
\text { ( } 791.2 \text { vs. } 697.1 \text { therapy } \\
\text { days per } 1000 \text { patient-days; } \\
\text { p=0.03), acid suppressant } \\
\text { medication use ( } 708.1 \\
\text { vs.372.4 days of therapy } \\
\text { per } 1000 \text { patient-days; } \\
\text { p=0.0001), and urinary } \\
\text { catheter use (0.3 vs. } 0.2 \\
\text { catheter-days per patient- } \\
\text { day; } p=0.002)\end{array}$ & $\begin{array}{l}\text { - Antimicrobial } \\
\text { resistance was not } \\
\text { assessed due to a } \\
\text { short one-year study } \\
\text { and were not able to } \\
\text { - Assess longer-term } \\
\text { effects } \\
\text { - No control group } \\
\text { was used } \\
\text { - Only one hospital } \\
\text { telemetry unit was } \\
\text { included in the study } \\
\text { The intervention was } \\
\text { performed twice a } \\
\text { week }\end{array}$ \\
\hline
\end{tabular}




\begin{tabular}{|c|c|c|c|c|c|}
\hline $\begin{array}{l}\text { Hamdy et al. } \\
\text { (2019) United } \\
\text { States }\end{array}$ & $\begin{array}{l}\text { To explore } \\
\text { perceptions of } \\
\text { pediatric nurse's } \\
\text { role in AS }\end{array}$ & $\begin{array}{l}\text { Qualitative, focus } \\
\text { groups/n=90 } \\
\text { nurses involved } \\
\text { in } 12 \text { focus group } \\
\text { study sessions } \\
\text { on } 10 \text { different } \\
\text { clinical units at } \\
\text { a freestanding } \\
\text { children's hospital }\end{array}$ & Theme 3 & $\begin{array}{l}\text { Nurses perceived their } \\
\text { important role in AS and } \\
\text { found they should play a } \\
\text { major role in AS desiring } \\
\text { additional education for } \\
\text { advocating for their patients } \\
\text { and communicating with } \\
\text { the team. Barriers included } \\
\text { inconsistent inclusion of } \\
\text { nurses on rounds and lack } \\
\text { of institutional protocols for } \\
\text { antibiotics }\end{array}$ & $\begin{array}{l}\text { Pediatric nurses from } \\
\text { one facility }\end{array}$ \\
\hline $\begin{array}{l}\text { Jeffs et al. } \\
\text { (2018) Canada }\end{array}$ & $\begin{array}{l}\text { To identify } \\
\text { strategies to } \\
\text { enhance nurses' } \\
\text { engagement in } \\
\text { ASPs and optimize } \\
\text { antimicrobial use }\end{array}$ & $\begin{array}{l}\text { Qualitative, } \\
\text { focus groups/ } \\
\mathrm{n}=25 \text { individuals } \\
\text { participating in } \\
6 \text { focus groups } \\
\text { (pharmacists ( } \mathrm{n}= \\
11), \text { physicians, }(\mathrm{n} \\
=7), \text { and nurses } \\
(\mathrm{n}=6) \text { who were } \\
\text { in management } \\
\text { roles, and one } \\
\text { unidentified) }\end{array}$ & Theme 6 & $\begin{array}{l}\text { Three key themes emerged } \\
\text { in this study including } \\
\text { (1) leveraging the interest } \\
\text { and passion of nurses; (2) } \\
\text { making it routine practice; } \\
\text { and (3) engaging nurses to } \\
\text { sustain and spread ASP by } \\
\text { nurse leaders }\end{array}$ & $\begin{array}{l}\text { The study included } \\
\text { nurses who were part } \\
\text { of the ASP team and } \\
\text { not those who were } \\
\text { recipients of local } \\
\text { specific projects. } \\
\text { - Social desirability } \\
\text { given the self-report } \\
\text { nature of the study } \\
\text { - Because the } 4 \\
\text { ICUs included in } \\
\text { the study were in } \\
\text { close proximity, } \\
\text { generalizability to } \\
\text { other settings may be } \\
\text { limited. }\end{array}$ \\
\hline $\begin{array}{l}\text { Kistler et al. } \\
\text { (2017) United } \\
\text { States }\end{array}$ & $\begin{array}{l}\text { To examine } \\
\text { the knowledge, } \\
\text { attitudes, and } \\
\text { behaviors of } \\
\text { suspected } \\
\text { infections among } \\
\text { nurses working } \\
\text { in nursing homes } \\
\text { and community- } \\
\text { dwelling older } \\
\text { adults }\end{array}$ & $\begin{array}{l}\text { Mixed method, } \\
\text { exploratory design } \\
\text { with convenience } \\
\text { samples } / n=32 \\
\text { nurses working in } \\
\text { nursing homes and } \\
n=66 \text { community } \\
\text { dwelling older } \\
\text { adults ( } \geq 65 \text { years } \\
\text { old) }\end{array}$ & $\begin{array}{l}\text { Themes } 1 \\
\text { and } 4\end{array}$ & $\begin{array}{l}\text { Almost all nurses } \\
\text { (94\%) disagreed or } \\
\text { strongly disagreed with } \\
\text { the statement "When } \\
\text { I have cold, I should } \\
\text { take antibiotics to } \\
\text { prevent getting a more } \\
\text { serious illness" (p. 5), as } \\
\text { compared to older adults } \\
\text { (77\%; p<.01) } \\
\text { Qualitative analysis } \\
\text { identified six themes, } \\
\text { four of which were } \\
\text { found among nurses and } \\
\text { older adults } \\
\text { The four common } \\
\text { themes included } \\
\text { further observation, } \\
\text { further work-up, } \\
\text { provider evaluation, } \\
\text { and non-pharmacologic } \\
\text { management The theme } \\
\text { unique to nurses was } \\
\text { following the protocol, } \\
\text { while uncertainty was } \\
\text { distinct to older adults. }\end{array}$ & $\begin{array}{l}\text { Select population and } \\
\text { sample size limits } \\
\text { generalizability }\end{array}$ \\
\hline
\end{tabular}




\begin{tabular}{|c|c|c|c|c|c|}
\hline $\begin{array}{l}\text { McGregor } \\
\text { et al. (2015) } \\
\text { Scotland }\end{array}$ & $\begin{array}{l}\text { To assess } \\
\text { knowledge of } \\
\text { antimicrobial } \\
\text { stewardship among } \\
\text { nurses given } \\
\text { the increasingly } \\
\text { important role } \\
\text { they play in the } \\
\text { administration of } \\
\text { antimicrobials }\end{array}$ & $\begin{array}{l}\text { Quantitative, } \\
\text { descriptive } \\
\text { survey design/ } \\
n=901 \text { nurses and } \\
\text { midwives ( } \mathrm{n}=855 \\
\text { completed an } \\
\text { online survey and } \\
\mathrm{n}=46 \text { completed } \\
\text { questions face-to- } \\
\text { face) }\end{array}$ & Theme 3 & $\begin{array}{l}\text { - } 36.1 \% \text { of the participants } \\
\text { rated their knowledge of } \\
\text { antibiotics as "good" or } \\
\text { "very good" while only } \\
\text { - } 21.5 \% \text { had heard of } \\
\text { the term "antimicrobial } \\
\text { stewardship" } \\
\text { - } 74.4 \% \text { indicated } \\
\text { that education } \\
\text { on antimicrobial } \\
\text { stewardship should } \\
\text { begin while obtaining } \\
\text { the degree, with a } \\
\text { preferred format as a } \\
\text { blend of styles (54.4\%) } \\
\text { - } 56.8 \% \text { thought that } \\
\text { the nurse/midwife } \\
\text { role should involve } \\
\text { ensuring appropriate } \\
\text { antimicrobial use and } \\
\text { the common challenge } \\
\text { to incorporating } \\
\text { antimicrobial } \\
\text { stewardship-based } \\
\text { practices was time } \\
\text { constraints/workload } \\
\text { (26.3\%) } \\
\text { The most cited type } \\
\text { of ongoing support } \\
\text { needed to take on } \\
\text { the antimicrobial } \\
\text { stewardship role was } \\
\text { support from various } \\
\text { sources such as } \\
\text { colleagues/management/ } \\
\text { clinicians (42.0\%) } \\
\end{array}$ & $\begin{array}{l}\text { Low response rate }(901 \\
\text { out of } 67,400\end{array}$ \\
\hline $\begin{array}{l}\text { Merrill et al. } \\
\text { (2019) United } \\
\text { States }\end{array}$ & $\begin{array}{l}\text { To evaluate nursing } \\
\text { knowledge related } \\
\text { to antimicrobial } \\
\text { stewardship } \\
\text { and their role in } \\
\text { contributing to } \\
\text { antimicrobial } \\
\text { endeavors }\end{array}$ & $\begin{array}{l}\text { Quantitative, } \\
\text { descriptive survey } \\
\text { design/n=316 } \\
\text { convenience sample } \\
\text { nurses from } 3 \\
\text { hospitals in an } \\
\text { integrated health } \\
\text { system in Utah. }\end{array}$ & Theme 3 & $\begin{array}{l}\text { - } 52 \% \text { were not familiar } \\
\text { with AS } \\
\text { - } 39.6 \% \text { felt and AS } \\
\text { program was important, } \\
\text { 95\% felt that they } \\
\text { should be involved in AS } \\
\text { interventions }\end{array}$ & $\begin{array}{l}\text { - The study only } \\
\text { included inpatient } \\
\text { nurses from } 3 \\
\text { hospitals within the } \\
\text { same health care } \\
\text { system } \\
\text { - The questions on the } \\
\text { survey may not have } \\
\text { been geared toward } \\
\text { nursing practice }\end{array}$ \\
\hline
\end{tabular}




\begin{tabular}{|c|c|c|c|c|c|}
\hline $\begin{array}{l}\text { Monsees et al. } \\
\text { (2018) United } \\
\text { States }\end{array}$ & $\begin{array}{l}\text { To identify the } \\
\text { nurse's confidence } \\
\text { in engaging in (AS) } \\
\text { practices within the } \\
\text { pediatric population }\end{array}$ & $\begin{array}{l}\text { Quantitative, } \\
\text { single-centered, } \\
\text { cross-sectional } \\
\text { survey study/n=180 } \\
\text { pediatric in-patient } \\
\text { staff nurses working } \\
\text { at a } 354 \text { bed } \\
\text { children's hospital }\end{array}$ & Theme 2 & \begin{tabular}{|l|} 
Nurses were confident \\
assessing the history of \\
adverse drug reactions, \\
patient education, and \\
obtaining cultures, \\
but less confident \\
understanding lab results \\
to determine antibiotic \\
appropriateness. \\
- Nurses were not \\
consistently included in \\
AS rounds and nursing \\
input was not actively \\
sought. \\
\end{tabular} & $\begin{array}{l}\text { - Only one hospital } \\
\text { (pediatric, with } \\
\text { infectious disease } \\
\text { physicians and } \\
\text { established } \\
\text { stewardship team) } \\
\text { were involved in } \\
\text { study } \\
\text { - The survey used } \\
\text { lacked formal testing } \\
\text { for reliability and } \\
\text { validity }\end{array}$ \\
\hline $\begin{array}{l}\text { Olans, } \\
\text { Nicholas et al, } \\
\text { (2015) United } \\
\text { States }\end{array}$ & $\begin{array}{l}\text { To examine how } \\
\text { nurses could be } \\
\text { included in ASPs } \\
\text { and what would } \\
\text { be needed to } \\
\text { accomplish this }\end{array}$ & $\begin{array}{l}\text { Mixed methods, } \\
\text { with two serial } \\
\text { surveys, using } \\
\text { Delphi process/ } \\
\mathrm{n}=10 \text { nurse } \\
\text { educators working } \\
\text { in a variety of } \\
\text { specialties from } \\
\text { 180-bed, 2-campus } \\
\text { community hospital } \\
\text { with an established } \\
\text { ASP }\end{array}$ & Theme 2 & $\begin{array}{l}\text { Results showed six areas } \\
\text { necessary for nurses } \\
\text { to have knowledge in } \\
\text { before they can make } \\
\text { meaningful contributions } \\
\text { to any ASP including: } \\
\text { 1. Skills in recognizing } \\
\text { early signs of infection } 2 . \\
\text { Being able to differentiate } \\
\text { between an infection and } \\
\text { organism colonization } \\
\text { 3. Understanding how to } \\
\text { interpret microbiology } \\
\text { lab results and how an } \\
\text { antibiogram should be } \\
\text { used when choosing } \\
\text { antibiotics } 4 \text {. Knowledge } \\
\text { about obtaining good } \\
\text { culture samples as well as } \\
\text { how well the laboratory } \\
\text { processes them 5. Knowing } \\
\text { when and which antibiotics } \\
\text { can be switched for oral } \\
\text { ones and when and how } \\
\text { broad-spectrum antibiotics } \\
\text { should be moderated to } \\
\text { narrower spectrum ones } \\
6 . \text { Increased confidence in } \\
\text { asking prescriber questions } \\
\text { about antimicrobials }\end{array}$ & Small sample size \\
\hline $\begin{array}{l}\text { Rout \& } \\
\text { Brysiewicz } \\
\text { (2017) South } \\
\text { Africa }\end{array}$ & $\begin{array}{l}\text { To explore the role } \\
\text { and the necessary } \\
\text { skills of the nurse } \\
\text { on an ASP }\end{array}$ & $\begin{array}{l}\text { Qualitative, } \\
\text { semi-structured } \\
\text { interviews } / \mathrm{n}=15 \\
\text { purposive sampling, } \\
\text { individuals } \\
\text { ( } 9 \text { nurses and } \\
8 \text { non-nurses } \\
\text { from disciplines } \\
\text { including medicine, } \\
\text { pharm, \& } \\
\text { microbiology) }\end{array}$ & Theme 3 & $\begin{array}{l}\text { Content analysis yielded } \\
\text { four themes including the } \\
\text { organizational role, the } \\
\text { advocacy role, the clinical } \\
\text { role and the collaborative } \\
\text { role }\end{array}$ & $\begin{array}{l}\text { The findings are } \\
\text { contextual, specific to } \\
\text { the hospital focused on } \\
\text { in the study }\end{array}$ \\
\hline
\end{tabular}




\begin{tabular}{|c|c|c|c|c|c|}
\hline $\begin{array}{l}\text { Scales et al. } \\
\text { (2016) United } \\
\text { States }\end{array}$ & $\begin{array}{l}\text { To assess } \\
\text { perspectives on } \\
\text { antibiotic use } \\
\text { and stewardship } \\
\text { among nurses and } \\
\text { providers }\end{array}$ & $\begin{array}{l}\text { Mixed method, } \\
\text { cross-sectional } \\
\text { survey/n=182 } \\
\text { nursing staff } \\
\text { (directors of } \\
\text { nursing, infection } \\
\text { control nurses, RNs, } \\
\text { LPNs); and n=50 } \\
\text { medical providers }\end{array}$ & Theme 5 & $\begin{array}{l}\text { Nurses are more ready } \\
\text { overall than medical } \\
\text { providers to implement } \\
\text { change regarding the } \\
\text { reduction of antibiotic use } \\
(3.6+/-0.8 \text { and } 2.9+/-0.9, \\
\text { respectively; } \mathrm{P}<.001)\end{array}$ & $\begin{array}{l}\text { The sample size and } \\
\text { region limited the } \\
\text { generalizability of this } \\
\text { study }\end{array}$ \\
\hline $\begin{array}{l}\text { Stuart et } \\
\text { al. (2015) } \\
\text { Australia }\end{array}$ & $\begin{array}{l}\text { To evaluate the role } \\
\text { of infection control } \\
\text { clinical nurse } \\
\text { consultants on the } \\
\text { ASP }\end{array}$ & $\begin{array}{l}\text { Quantitative, } \\
\text { pre-during-post } \\
\text { intervention } \\
\text { pilot study/n=2 } \\
\text { residential aged } \\
\text { care facilities (with } \\
\text { a total of } 130 \text { beds) }\end{array}$ & Theme 3 & $\begin{array}{l}\text { Results showed that } 102 \\
\text { antimicrobials were ordered } \\
\text { and given at baseline and } \\
83 \text { after the completion of } \\
\text { the intervention, yielding } \\
\text { a significant reduction } \\
\text { in the total number of } \\
\text { antimicrobials prescribed } \\
\text { in a given number of days } \\
(\mathrm{P}<.0001)\end{array}$ & $\begin{array}{l}\text { Select population and } \\
\text { sample size limits } \\
\text { generalizability }\end{array}$ \\
\hline $\begin{array}{l}\text { Wilson et al. } \\
\text { (2017) United } \\
\text { States }\end{array}$ & $\begin{array}{l}\text { To assess nurses' } \\
\text { awareness of } \\
\text { their function in } \\
\text { antimicrobials } \\
\text { stewardship in a } \\
\text { long-term care } \\
\text { setting }\end{array}$ & $\begin{array}{l}\text { Quantitative, paired } \\
\text { pre- and post-course } \\
\text { survey/n=103 } \\
\text { nurses ( } 71 \text { RNs and } \\
32 \text { LPNs) working } \\
\text { at a community- } \\
\text { based nursing home }\end{array}$ & Theme 2 & $\begin{array}{l}\text { Post intervention results } \\
\text { showed a statistically } \\
\text { significant improvement in } \\
\text { the number of knowledge- } \\
\text { based questions answered } \\
\text { correctly (75\%-86\%: } \\
\mathrm{P}<.001)\end{array}$ & $\begin{array}{ll}\text { - A relatively small } \\
\text { sample size with } \\
50 \% \text { attrition rate } \\
\text { - Potential of social } \\
\text { desirability bias } \\
\text { - Lack of } \\
\text { differentiation } \\
\text { between educational } \\
\text { backgrounds and } \\
\text { professional roles } \\
\text { - Some survey items } \\
\text { were not validated }\end{array}$ \\
\hline
\end{tabular}

Note: ${ }^{\text {a. }}$ Theme $1=$ nurses' competency requirement and training related to antimicrobial stewardship: Theme $2=$ antimicrobial knowledge and training/educational gaps, Theme $3=$ role of the nurse; Theme $4=$ nurses' attitudes toward antimicrobial use; Theme $5=$ nurse and provider perspectives on ASP; and Theme 6=nurses' valuable contributions to antimicrobial stewardship.

\section{References}

Abbas, S., Lee, K., Pakyz, A., Markley, D., Cooper, K., Vanhoozer, G., Doll, M., Bearman, S., \& Stevens, M. P. (2019). Knowledge, attitudes, and practices of bedside nursing staff regarding antibiotic stewardship: A cross-sectional study. American Journal of Infection Control, 47(3), 230-233. https:// dx.doi.org/10.1016/j.ajic.2018.09.008

American Nurses Association \& Centers for Disease Control and Prevention (2017). Redefining the antibiotic stewardship team: Recommendations from the American Nurses Association/ Centers for Disease Control and Prevention workgroup on the role of registered nurses in hospital antibiotic stewardship practices. Silver Spring, MD: American Nurse Association. https://www.cdc.gov/antibiotic-use/healthcare/pdfs/ANACDC-whitepaper.pdf

Cadavid, C. C., Sakamoto, S. D., Terashita, D. M., \& Schwartz, B. (2017). Bedside registered nurse roles in antimicrobial stewardship: A survey of acute-care hospitals in Los Angeles
County. Infection Control \& Hospital Epidemiology, 38(10), 1263-1265. https://dx.doi.org/10.1017/ice.2017.166

Carter, E. J., Greendyke, W. G., Furuya, E. Y., Srinivasan, A., Shelley, A. N., Bothra, A., Saiman, L., \& Larson, E. L. (2018). Exploring the nurses' role in antibiotic stewardship: A multisite qualitative study of nurses and infection preventionists. American Journal of Infection Control, 46(5), 492-497. https:// dx.doi.org/10.1016/j.ajic.2017.12.016

Centers for Disease Control and Prevention. (2019). Core elements of hospital antibiotic stewardship programs. https://www.cdc. gov/antibiotic-use/core-elements/hospital.html

Fisher, C. C., Cox, V. C., Gorman, S. K., Lesko, N., Holdsworth, K., Delany, N., \& McKenna, C. (2018). A theory-informed assessment of the barriers and facilitators to nurse-driven antimicrobial stewardship. American Journal of Infection Control, 46(12), 1365-1369. https://dx.doi.org/10.1016/j. ajic.2018.05.020 
Gillespie, E., Rodrigues, A., Wright, L., Williams, N., \& Stuart, R. L. (2013). Improving antibiotic stewardship by involving nurses. American Journal of Infection Control, 41(4), 365-370. https://dx.doi.org/10.1016/j.ajic.2012.04.336

Greendyke, W. G., Carter, E. J., Salsgiver, E., Bernstein, D., Simon, M. S., Saiman, L., Calfee, D., \& Furuya, E. Y. (2018). Exploring the role of the bedside nurse in antimicrobial stewardship: Survey results from five acute-care hospitals. Infection Control \& Hospital Epidemiology, 39(3), 360-362. https://dx.doi.org/10.1017/ice.2017.255

Ha, D. R., Forte, M. B., Olans, R. D., O'Yong, K., Olans, R. N., Gluckstein, D. P., Kullar, R.,Desai, M., Catipon, N., Ancheta, V., Lira, D., Khattak, Y., Legge, J., Nguyen, K. B.,Chan, S., Mourani, J., \& McKinnell, J. A. (2019). A multidisciplinary approach to incorporate bedside nurses into antimicrobial stewardship and infection prevention. Joint Commission Journal on Quality and Patient Safety, 45(9), 600-605. https:// dx.doi.org/10.1016/j.jcjq.2019.03.003

Hamdy, R., Neal, W., Nicholson, L., Ansusinha, E., \& King, S. (2019). Pediatric nurses' perceptions of their role in antimicrobial stewardship: A focus group study. Journal of Pediatric Nursing, 48(1), 10-17. https://dx.doi.org/10.1016/j. pedn.2019.05.020

Jeffs, L., Law, M. P., Zahradnik, M., Steinberg, M., Maione, M., Jorgoni, L., Bell, C.M., \& Morris, A. M. (2018). Engaging nurses in optimizing antimicrobial use in ICUs: A qualitative study. Journal of Nursing Care Quality, 33(2), 173-179. https:// dx.doi.org/10.1097/NCQ.0000000000000281

Kelly, P. (2008). Nursing leadership \& Management. Delmar Cengage Learning.

Kistler, C. E., Beeber, A., Becker-Dreps, S., Ward, K., Meade, M., Ross, B., \& Sloane, P. D. (2017). Nursing home nurses' and community-dwelling older adults' reported knowledge, attitudes, and behavior toward antibiotic use. BMC Nursing, 16(12), 1-7. https://dx.doi.org/10.1186/s12912-017-0203-9

Manning, M. L., Pfeiffer, J., \& Larson, E. L. (2016). Combating antibiotic resistance: The role ofnursing in antibiotic stewardship. American Journal of Infection Control, 44(12), 1454-1457. https://dx.doi.org/10.1016/j.ajic.2016.06.023

McGregor, W., Brailey, A., Walker, G., Bayne, G., Sneddon, J., \& McEwen, J. (2015).Assessing knowledge of antimicrobial stewardship. Nursing Times, 111(21), 15-17.

Merrill, K., Hanson, S. F., Sumner, S., Vento, T., Veillette, J., \& Webb, B. (2019). Antimicrobial stewardship: Staff nurse knowledge and attitudes. American Journal of Infection
Control, 47(10), 1219-1224. https://dx.doi.org/10.1016/j. ajic.2019.03.022

Monsees, E., Popejoy, L., Jackson, M. A., Lee, B., \& Goldman, J. (2018). Integrating staff nurses in antibiotic stewardship: Opportunities and barriers. American Journal of Infection Control, 46(7), 737-742. https://dx.doi.org/10.1016/j. ajic.2018.03.028

Olans, R. D., Nicholas, P. K., Hanley, D., \& DeMaria, A. (2015). Defining a role for nursing education in staff nurse participation in antimicrobial stewardship. Journal of Continuing Education in Nursing, 46(7), 318-321. https:// dx.doi.org/10.3928/00220124-20150619-03

Olans, R. N., Olans, R. D., \& DeMaria, A. (2016). The critical role of the staff nurse in antimicrobial stewardship. Unrecognized, but already there. Clinical Infectious Diseases, 62(1), 84-89. https://dx.doi.org/10.1093/cid/civ697

Rout, J. \& Brysiewicz, P. (2017). Exploring the role of the ICU nurse in the antimicrobial stewardship team at a private hospital in KwaZulu-Natal, South Africa. Southern African Journal of Critical Care, 33(2), 46-50. https://dx.doi.org/10.7196/ SAJCC.2017.v33i2.331

Scales, K., Zimmerman, S., Reed, D., Beeber, A. S., Kistler, C. E., Preisser, J. S., Weiner, B.J., Ward, K., Fann, A., \& Sloane, P. D. (2016). Nurse and medical provider perspectives on antibiotic stewardship in nursing homes. Journal of the American Geriatrics Society, 65(1), 165-171. https://dx.doi.org/10.1111/ jgs. 14504

Society for Healthcare Epidemiology of America, Infectious Diseases Society of America \& Pediatric Infectious Diseases Society (2012). Policy statement on antimicrobial stewardship by the Society for Healthcare Epidemiology of America (SHEA), the Infectious Diseases Society of America (IDSA), and the Pediatric Infectious Diseases Society (PIDS). Infection Control and Hospital Epidemiology, 33(4), 322-327. https:// dx.doi.org/10.1086/665010

Stuart, R. L., Orr, E., Kotsanas, D., \& Gillespie, E. E. (2015). A nurse-led antimicrobial stewardship intervention in two residential aged care facilities. Healthcare Infection, 20(1), 4-6. http://dx.doi.org/10.1071/HI14016

Wilson, B. M., Shick, S., Carter, R. R., Heath, B., Higgins, P. A., Sychla, B., Olds, D.M., \& Jump,R. L. P. (2017). An online course improves nurses' awareness of their role as antimicrobial stewards in nursing homes. American Journal of Infection Control, 45(5), 466-470. https://dx.doi.org/10.1016/j. ajic.2017.01.002 